\title{
Study on Water Disaster Prevention and Control Technology under Condition of Extra-thick Coal Seam with Slicing Full- mechanized Caving Mining
}

\author{
Jianghua $\mathrm{Li}^{1,2,3, *}$, Yuguang Lian ${ }^{1,2}$, and Hongjie $\mathrm{Li}^{1,2}$ \\ ${ }^{1}$ Mine Safety Technology Branch of China Coal Research Institute, Beijing 100013, China \\ ${ }^{2}$ State Key Laboratory of Coal Mining and Clean Utilization, China Coal Research Institute, Beijing 100013, China \\ ${ }^{3}$ Faculty of Geoscience and Surveying Engineering, China University of Mining and Technology (Beijing), Beijing 100083, China
}

\begin{abstract}
Some coal seams belong to cretaceous strata in the east of Inner Mongolia, China. There are obvious differences of rock characteristics and mechanical properties between Cretaceous and CarboniferousPermian strata. The overburden failure characteristics of extra-thick coal seam with slicing full-mechanized caving mining are studied through rock mechanics experiment, field observation and theoretical analysis and so on. Water disaster prevention and control method of roof and goaf is put forward under the condition of extra-thick coal seam with slicing full-mechanized caving mining. The final research results include: (1) The rock of cretaceous strata has low strength and soft characteristic, its stability is very poor, cretaceous rock belongs to weak type; (2) Under the condition of extra-thick coal seam with slicing full-mechanized caving mining, the ratio between caving zone and mining height of field observation result is $4.58 \sim 4.74$, the observation results of two boreholes are close; (3) It is significantly effective to prevent and control water disaster from goaf through roof hole drainage method, coal and rock safety pillar remain method is used to limit mining height under the Tertiary gravel aquifer, which makes the working face exploit safely.
\end{abstract}

\section{Introduction}

The coal mine hydrogeological condition of China is very complex and rarely seen in the word ${ }^{[1,2]}$. Loose aquifers generally exist in the flat area in north, northeast and east of China, where coal field shallow possesses the problem of mining under aquifers. Coal mines are under the threat of aquifers during exploitation process ${ }^{[3]}$. At present, safety mining technology under quaternary and ternary loose aquifers has obtained significant progress and applied in many coal mines with the deeper and more extensive research of domestic and foreign scholars ${ }^{[4]}$. However, some thick and extra-thick coal seams reserves in cretaceous strata in the east of Inner Mongolia. Mining power could make the roof strata rupture greatly and bring bad influence to safety production, when the fissure zone connects the aquifers.

The key to prevent and control water disasters is mastering the overburden failure rules and state distribution characteristics. The height of caving zone and fissure zone are the important basis of water disaster forecast and waterproof safety coal and rock pillar design ${ }^{[5-7]}$. The research on overburden failure characteristics acquires breakthrough with the rapid expansion of fully mechanized mining technology ${ }^{[8]}$. However, the previous research on overburden failure rules focuses on Carboniferous-Permian and Jurassic strata and is short of Cretaceous strata, especially for the extra-thick coal seam with slicing full-mechanized caving mining [9]. Take Duolun coal mine as an example, the height of No.7 coal seam is $15.8 \mathrm{~m}$, using the method of slicing fullmechanized caving mining. There are ternary loose aquifer and higher slice goaf water upon the working face of lower slice coal seam. This paper researches overburden failure characteristics of extra-thick coal seam with slicing full-mechanized caving mining through rock mechanics experiment, field observation and theoretical analysis. Water disaster prevention and control methods of roof and goaf are put forward, which provides guarantee for safety mining.

\section{Mine profile}

Duolun mine has the designed production capacity of $1.20 \mathrm{Mt} / \mathrm{a}$, and exploits No.7 coal seam with average thickness of $15.80 \mathrm{~m}$ located in cretaceous strata. Coalbearing stratum of the well field locates in a faulted synclinal basin with north-south extension, length of $6000 \mathrm{~m}$ and width of $300 \sim 1400 \mathrm{~m}$. Part of No.7 coal seam suboutcrop is integrated into ternary strata and locates

\footnotetext{
*Corresponding author: Jianghua_Lee@163.com
} 
under ternary aquifer.

All of the ten working faces $\left(1700^{-1} \sim 1709^{-1}\right)$ of top slice No.7 coal seam has been exploited until 4/18, 2017. At parent, the mine is exploiting $1704^{-2}$ working face with length of $528 \mathrm{~m}$, width of $130 \mathrm{~m}$, located in lower slice of No.7 coal seam, the north of No.1 mining area. Open-off cut of $1704^{-2}$ working face closes to north of mine boundary, mining from north to south. Boreholes reveal the thickness of No. 7 coal seam is $5.42 \sim 15.35 \mathrm{~m}$ and the thickness of bed rock is $55.0 \sim 74.9 \mathrm{~m}$ in $1704^{-2}$ working face. The goaf waterlogged areas of $1702^{-1}$ and $1704^{-1}$ working faces and ternary aquifer have an influence on $1704^{-2}$ working face. According to pumping test results and "detailed rule of coal mine water control and prevention", the tertiary gravel aquifer belongs to weak watery with unit inflow of $0.0146 \sim 0.0517 \mathrm{~L} / \mathrm{s} \cdot \mathrm{m}^{[10]}$.

\section{Physical and mechanical properties of cretaceous rock}

\subsection{Rock mechanical parameter test}

Rock cores are gathered from roof strata of No.7 coal seam in surface borehole and processed into standard rock samples in the rock mechanical laboratory. Rock samples can be used for uniaxial compressive strength test, apparent density test and softening coefficient test. The stress-strain curve of rock uniaxial compressive strength is shown in Figure1 and the test results of rock mechanical parameter are shown in Table 1.

The uniaxial compressive strength of roof rock of No.7 coal seam is $1.4 \sim 11.6 \mathrm{MPa}$, softening coefficient is $0.20 \sim 0.60$, which indicate the rock of cretaceous strata has low strength, and soft characteristic, poor stability.

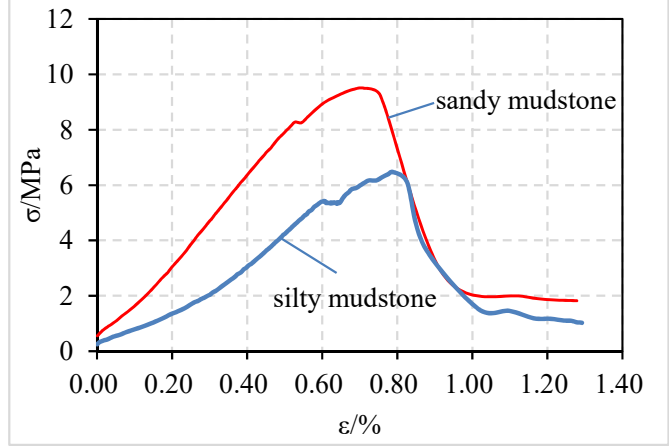

Fig. 1. Stress-strain curve of uniaxial compressive strength

Table 1. Physical and mechanical parameters of rock

\begin{tabular}{|c|c|c|c|c|c|}
\hline Lithology & $\begin{array}{c}\text { apparent } \\
\text { density } \\
\mathbf{( k g} \cdot \mathbf{m}^{-3} \mathbf{)}\end{array}$ & $\begin{array}{c}\text { Compressive } \\
\text { strength } \\
\mathbf{( M P a})\end{array}$ & $\begin{array}{c}\text { Softening } \\
\text { coefficient }\end{array}$ & $\begin{array}{c}\text { Elasticity } \\
\text { modulus } \\
\mathbf{( G P a )}\end{array}$ & $\begin{array}{c}\text { Poisson } \\
\text { ratio }\end{array}$ \\
\hline $\begin{array}{c}\text { Fine } \\
\text { sandstone }\end{array}$ & $\frac{1855 \sim 2620}{2238}$ & $\frac{3.8 \sim 7.2}{6.8}$ & $\frac{0.41 \sim 0.48}{0.46}$ & $\frac{0.92 \sim 1.83}{1.52}$ & $\frac{0.24 \sim 0.30}{0.28}$ \\
\hline Mudstone & $\frac{1625 \sim 2200}{1753}$ & $\frac{1.4 \sim 11.6}{5.8}$ & $\frac{0.24 \sim 0.60}{0.34}$ & $\frac{3.28 \sim 7.44}{5.36}$ & $\frac{0.19 \sim 0.29}{0.24}$ \\
\hline $\begin{array}{c}\text { Sandy } \\
\text { mudstone }\end{array}$ & $\frac{1801 \sim 1936}{1860}$ & $\frac{4.9 \sim 9.0}{7.0}$ & 0.60 & $\frac{0.52 \sim 1.63}{1.03}$ & $\frac{0.30 \sim 0.34}{0.32}$ \\
\hline
\end{tabular}

\begin{tabular}{|c|c|c|c|c|c|}
\hline $\begin{array}{c}\text { Silty } \\
\text { mudstone }\end{array}$ & $\frac{1963 \sim 2031}{1999}$ & $\frac{4.5 \sim 6.4}{5.3}$ & $\frac{0.20 \sim 0.43}{0.30}$ & $\frac{0.67 \sim 1.32}{0.96}$ & $\frac{0.30 \sim 0.33}{0.32}$ \\
\hline $\begin{array}{c}\text { Carbon } \\
\text { mudstone }\end{array}$ & $\frac{1816 \sim 1922}{1846}$ & $\frac{3.6 \sim 7.1}{5.6}$ & $/$ & 1.22 & 0.31 \\
\hline
\end{tabular}

\subsection{Overburden type}

The roof rock strata of No.7 coal seam is composed of mud rock and sandstone through analyzing 50 geological drills' data from coal field. The bedrock is divided into four sections which are $0 \sim 20 \mathrm{~m}, 20 \sim 40 \mathrm{~m}, 40 \sim 60 \mathrm{~m}$ and $>60 \mathrm{~m}$ from No. 7 coal seam to the top of bedrock. The mud rock proportion of each section is $54.10 \%$, $53.50 \%, 53.80 \%$ and $49.59 \%$, each section closes to $50 \%$ (as shown in Table 2). So mud rock of overburden rock strata belongs to moderate proportion. However, due to the low strength of cretaceous rock and the late diagenesis of cretaceous strata, the roof rock is classified as weak type.

Table 2. Lithology combined characters of overlying strata

\begin{tabular}{|c|c|c|c|c|}
\hline $\begin{array}{c}\text { Subsection } \\
\text { of roof }\end{array}$ & $\begin{array}{c}\text { Sandstone } \\
\text { thickness } \\
(\mathbf{m})\end{array}$ & $\begin{array}{c}\text { Sandstone } \\
\text { percentage } \\
(\mathbf{\%})\end{array}$ & $\begin{array}{c}\text { Mudstone } \\
\text { thickness } \\
(\mathbf{m})\end{array}$ & $\begin{array}{c}\text { Mudstone } \\
\text { percentage } \\
(\%)\end{array}$ \\
\hline $0-20 \mathrm{~m}$ & 9.18 & 45.90 & 10.82 & 54.10 \\
\hline $20-40 \mathrm{~m}$ & 9.30 & 46.50 & 10.70 & 53.50 \\
\hline $40-60 \mathrm{~m}$ & 9.24 & 46.20 & 10.76 & 53.80 \\
\hline$>60 \mathrm{~m}$ & 31.69 & 50.41 & 31.17 & 49.59 \\
\hline
\end{tabular}

\section{The caving zone height of extra-thick coal seam with slicing full-mechanized caving mining}

\subsection{Observation results of caving zone}

The depth of No.7 coal seam in Duolun coal mine is less than $400 \mathrm{~m}$, relatively shallow. It is feasible and rational for technology and economy to observe the height of caving zone through ground borehole [11,12]. The diagrammatic sketch of caving zone observation is shown in Figure 2.

The bed rock thickness of $1703^{-2}$ working face is more than $140 \mathrm{~m}$. According to "Preliminary design of Duolun coal mine", working face $1703^{-2}$ can be mined with slicing full-mechanized caving mining. So on the earth's surface of working face $1703^{-2}$, two observation holes (17-SD1 and 17-SD2) are designed in the 'saddle' peak area of caving zone. The location of observation holes is shown in Figure 3. To obtain the maximum height of caving zone, the location of observation holes should have been exploited about one month before drilling to the peak of caving zone. 


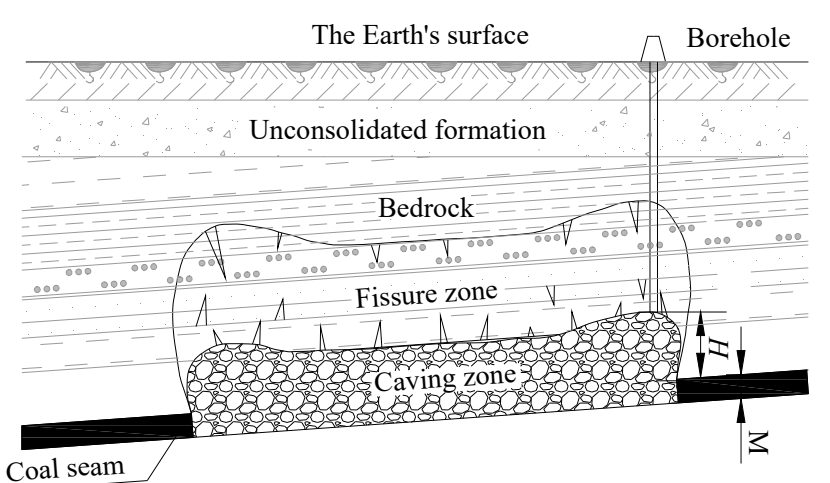

Fig. 2. Diagrammatic sketch of caving zone observation

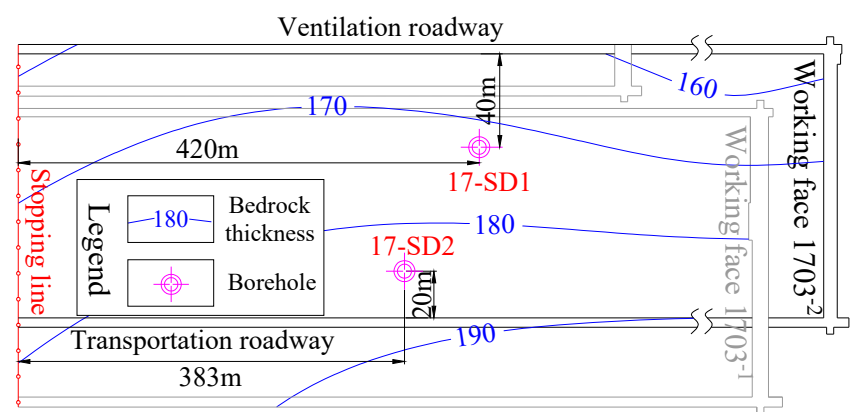

Fig. 3. Sketch map of observation borehole location

Water level variation of borehole is shown in Figure 4. The bedrock section of caving zone borehole is drilled with clear water. Water level of both boreholes drops significantly when drilling depth reaches $222.72 \mathrm{~m}$ and $234.43 \mathrm{~m}$ each one. The phenomenon of "drill bit falling" happens in the depth of $226.72 \mathrm{~m}$ and $238.43 \mathrm{~m}$ each borehole. Drilling speed sometimes is fast, sometimes is slow, drilling tool shook more intensively, and "falling and sticking drills" phenomenon occurred. Borehole has distinct suction phenomenon, and the core had high fragmentation degree, low extraction ratio, many stagger cracks, and disorganized stratification and angles (as shown in Figure 5). On the basis of above analysis, it is regarded that this position is the peak of caving zone.

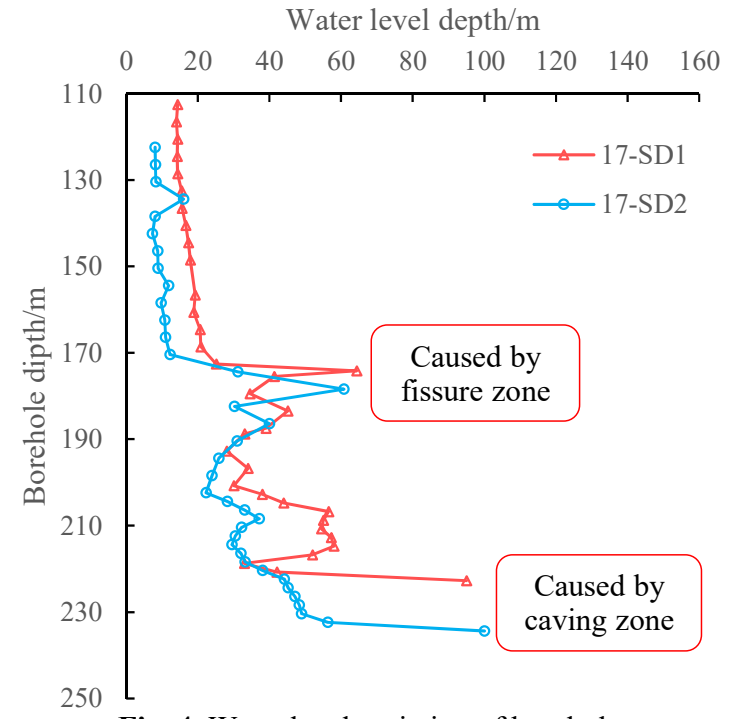

Fig. 4. Water level variation of boreholes

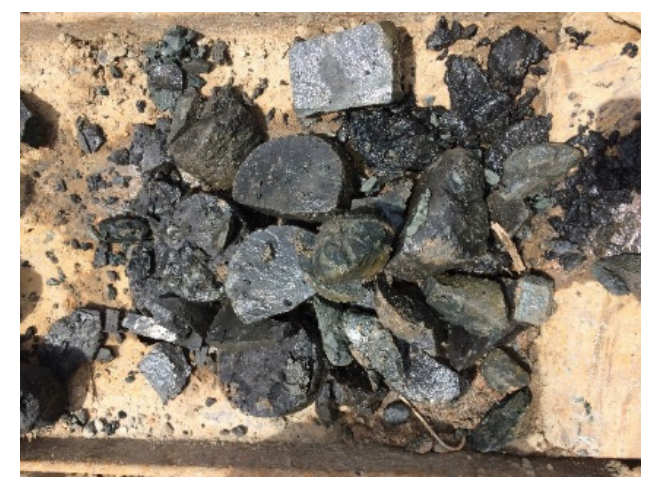

Fig. 5. Rock core of caving zone

\subsection{Calculation of caving zone height}

Based on the statistics of mining height of 17-SD1 and $17-\mathrm{SD} 2$, the accumulative total mining height is $15.72 \mathrm{~m}$ and $15.08 \mathrm{~m}$ respectively. The calculation formula of caving zone height as follow:

$$
H_{k}=Z_{k}-Z_{d}-M_{z}-h_{k}
$$

Where $H_{k}$ is caving zone height; $Z_{k}$ is borehole initial elevation; $Z_{d}$ is the coal floor elevation; $H_{k}$ is the peak depth of caving zone; $M z$ is the total of mining thickness.

Under the condition of slicing full-mechanized caving mining, calculation results of caving zone height are shown in Table 3. The ratio between caving zone height and mining height is $4.58 \sim 4.74$, observation results of two boreholes have good consistency.

Table 3. Measure value of caving zones

\begin{tabular}{|c|c|c|}
\hline Borehole no. & $17-\mathrm{SD} 1$ & $17-\mathrm{SD} 2$ \\
\hline $\boldsymbol{Z}_{\boldsymbol{k}}(\mathbf{m})$ & 1254.20 & 1255.64 \\
\hline $\boldsymbol{Z}_{\boldsymbol{d}}(\mathbf{m})$ & 943.79 & 935.13 \\
\hline $\boldsymbol{H}_{\boldsymbol{k}}(\mathbf{m})$ & 222.72 & 234.43 \\
\hline $\boldsymbol{H}_{\boldsymbol{k}}(\mathbf{m})$ & 71.976 & 71.468 \\
\hline $\boldsymbol{M z}(\mathbf{m})$ & 15.72 & 15.08 \\
\hline $\boldsymbol{H}_{\boldsymbol{k}} \boldsymbol{M} \boldsymbol{z}$ & 4.58 & 4.74 \\
\hline
\end{tabular}




\section{Water disaster prevention and control of working face $1704^{-2}$}

\subsection{Goaf water control and prevention}

The working face $1704^{-2}$ is located in the bottom of $1702^{-}$ ${ }^{1}$ and $1704^{-1}$. The mining fissure of roof rock will conduct the goaf of working face $1702^{-1}$ and $1704^{-1}$ when mining working face $1704^{-2}$. The goaf water may inrush stope instantaneously and induce catastrophic accident, which threats safety production of working face.
In order to eliminate the hidden danger of goaf water and guarantee safety mining, 2 drill sites and 7 boreholes are designed in the transportation roadway, 3 drill sites and 10 boreholes are designed in the open-off cut and 3 drill sites and 21 boreholes are designed in the ventilation roadway during the period of ventilation roadway. All of the final location of boreholes reach the bottom of goaf. The total of boreholes are 38 and total footage is $1830.5 \mathrm{~m}$. Boreholes in the area near open-off cut is shown in Figure 6. The total of water inrush boreholes is 6 and the maximum water inflow is $12.5 \mathrm{~m}^{3} / \mathrm{h}$ (as shown in Table 4). The total water inflow is less than $3 \mathrm{~m}^{3} / \mathrm{h}$ after one month's dewatering.

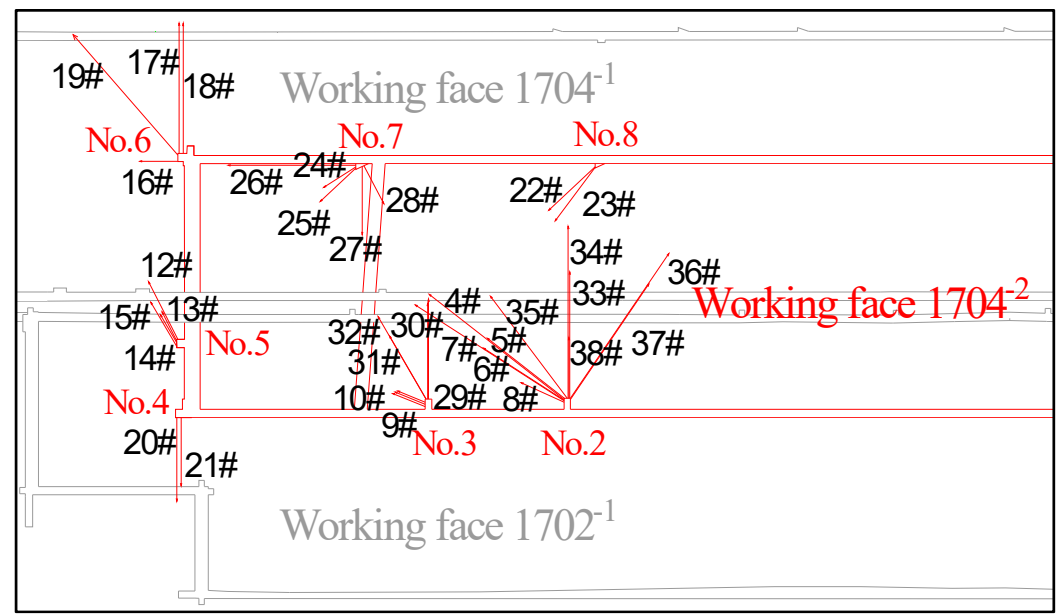

Figure. 6. Boreholes in the area near open-off cut

Table 4. Records of water inrush boreholes

\begin{tabular}{|c|c|c|c|c|c|c|}
\hline $\begin{array}{c}\text { Borehole site } \\
\text { location }\end{array}$ & $\begin{array}{c}\text { Borehole } \\
\text { no. }\end{array}$ & $\begin{array}{c}\text { Azimuth } \\
\text { angle ( } \mathbf{(}^{\circ}\end{array}$ & Dip angle $\left(^{\circ}\right)$ & Depth (m) & $\begin{array}{c}\text { Water inrush } \\
\text { location (m) }\end{array}$ & $\begin{array}{c}\text { Water inflow } \\
\left(\mathbf{m}^{\mathbf{3}} / \mathbf{h}\right)\end{array}$ \\
\hline \multirow{2}{*}{ NO.2 } & $6 \#$ & $30^{\circ}$ & $15^{\circ}$ & 52.5 & 46 & 1 \\
\cline { 2 - 7 } & $8 \#$ & $22^{\circ}$ & $8^{\circ}$ & 25.5 & 19 & 1 \\
\hline \multirow{2}{*}{ NO.8 } & $22 \#$ & $320^{\circ}$ & $15^{\circ}$ & 38 & 36 and 38 & 5 and 12.5 \\
\cline { 2 - 7 } & $23 \#$ & $310^{\circ}$ & $15^{\circ}$ & 39 & 37 and 39 & 1 and 2 \\
\hline \multirow{2}{*}{ NO.7 } & $27 \#$ & $270^{\circ}$ & $10^{\circ}$ & 34 & 21 and 34 & 3 and 3 \\
\cline { 2 - 7 } & $28 \#$ & $240^{\circ}$ & $10^{\circ}$ & 23 & 17 and 23 & 3 and 3 \\
\hline
\end{tabular}

\subsection{Gravel aquifer control and prevention}

\subsubsection{Designing method of safety coal and rock pillar}

According to the boundary of gravel aquifer, the working face $1704^{-2}$ is divided into 2 areas which are clay bottom area (Area I) and gravel bottom area (Area II). The gravel aquifer is nonexistent in the clay bottom area (as shown in Figure 7). Based on the research of hydrogeological condition and "Rules for the prevention and control of water in coal mine", caving-proof safety coal and rock pillar can be designed in the Area I, that is, the design value of caving-proof safety coal and rock pillar should not be more than the thickness of bed rock. Sand-proof safety coal and rock pillar can be designed in the Area II, that is, the design value of sand-proof safety coal and rock pillar should not be more than the thickness of bed rock. Sand-proof safety coal and rock pillar consists of caving zone height and the thickness of protective layer. Caving height is 4.74 (choosing the maximum value of field observation) times of mining height and the thickness of protective layer is 2.8 times of mining height. 


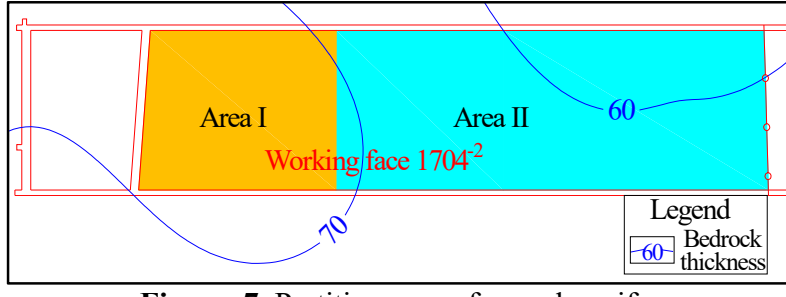

Figure. 7. Partition map of gravel aquifer

\subsubsection{Design of safety coal and rock pillar}

\section{(a) Area I}

According to the mining condition of working face $1702^{-1}$ and $1704^{-1}$, the top layer of No.7 coal seam has been mined $8.1 \mathrm{~m}$. Based on the contour map of bed rock thickness (as shown in Figure 7), the bed rock thickness is about $70 \sim 74.9 \mathrm{~m}$. Safety mining thickness of working face $1704^{-2}$ can be calculated on the basis of the minimum value of $70 \mathrm{~m}$. That is,

$$
4.74(8.1+\mathrm{A}) \leq 70 \mathrm{~m}
$$

Where $\mathrm{A}$ is the allowable mining height.

Then $A \leq 6.67 \mathrm{~m}$, so the maximum allowable thickness of mining is $3.5 \mathrm{~m}$ in area $\mathrm{I}$.

(b) Area II

The thickness of low layer is $9 \mathrm{~m}$ through roadway exploration. More than $5 \mathrm{~m}$ of low layer which will not be mined can be made as part of sand-proof safety coal and rock pillar, so the thickness of bed rock is about $60 \sim 70 \mathrm{~m}$. Safety mining thickness of area II can be calculated on the basis of the minimum value of $60 \mathrm{~m}$. That is,

$$
4.74 \times(8.1+\mathrm{A})+2.8 \mathrm{~A} \leq 60 \mathrm{~m}
$$

Then $\mathrm{A} \leq 2.86 \mathrm{~m}$, so the maximum allowable thickness of mining is $2.86 \mathrm{~m}$ in area II.

The mining heights of different areas are shown in Table 5.

Table 5. Mining heights of different areas

\begin{tabular}{|c|c|c|}
\hline Area & Area I & Area II \\
\hline $\begin{array}{c}\text { Bedrock thickness } \\
\text { (m) }\end{array}$ & $70 \sim 74.9$ & $60 \sim 70$ \\
\hline $\begin{array}{c}\text { Mining length (m) } \\
\text { Mining height (m) }\end{array}$ & $0 \sim 165$ & $165 \sim 528$ \\
\hline
\end{tabular}

\section{Conclusions}

(1) Based on rock mechanics experiment, the uniaxial compressive strength of roof rock of No.7 coal seam is $1.4 \sim 11.6 \mathrm{MPa}$, softening coefficient is $0.20 \sim 0.60$, which indicates the rock of cretaceous strata has low strength, and soft characteristic, poor stability.

(2) Through the methods of field measurement and theoretical analysis, this paper researches the damage characteristics of overburden rock with slicing fullmechanized caving mining in cretaceous strata. It can be concluded that the ratio between caving zone height and mining height is about $4.58 \sim 4.74$. Choosing the maximum value (4.74) of field observation as the design parameter of safety coal and rock pillar.

(3) Dewatering the goaf water of working face $1702^{-1}$ and $1704^{-1}$ through roof boreholes. Preventing and controlling the gravel aquifer through the method of designing reasonable safety coal and rock pillar. The two prevention and control methods of roof water disaster make the safety mining come true.

\section{Acknowledgment}

Foundation projects: Basic Research Foundation of China Coal Research Institute (2017JC07); National Science and Technology Major Project (2016ZX05045001-004); National Natural Science Foundation Project (51674142).

\section{References}

1. J.H. Li, Y.C. Xu, J.P. Dong, W.Y. Guo, X.C. Cao. JCCS, 41, 984-991 (2016)

2. C. Niu, L.Q. Shi, L.L. Xiao, P.H. Zhai, S.L. Wu, Y.H. Zhao. S CM, 46, 208-211 (2015)

3. S.Q. Zhao, Q. Wu, S.X. Yin. CE, 48, 9-11 (2016)

4. Y.C. Xu, S.Q. Liu. CST, 39, 1-4 (2011)

5. H.W. Zhang, Z.J. Zhu, L.J. Huo. JCCS, 39, 816-821 (2014)

6. Y.C. Xu, S.Q. Liu, Z.X. Liu. JMSE, 30,506-511 (2013)

7. W.X. Wang, W.H. Sui, H.Q. Dong. JCCS, 38, 17281734 (2013)

8. Z.Y. Shu, L. Li, H.J. Li. CST, 44, 52-54 (2016)

9. J.H. Li, Y.C. Xu, W.Z. Gu. IJMME, 6, 276-293 (2015)

10. National Coal Industrial Bureau. Rules for coalmining relating to building, water body, railway and main tunnel. (2000)

11. L.F. Wang, W.D. Li, D.W. Liu, G. L. JMSEP, 32, 70 $71(2005)$

12. Y.C. Xu, Z.H. Li, A.L. Jia. CST, 38, 21-23 (2010)

13. Y.F. Ren, Y. Ning, Q.X. Qi. JCCS, 38, 61-66 (2013)

14. W.X. Wang, W.H. Sui, H.Q. Dong. JCCS, 38,17281734 (2013) 